\title{
RANCANG BANGUN ALAT PENGGILING DAN PENGERING CABAI MENGGUNAKAN ATMEGA 328
}

\author{
Vida Cahya Guntara ${ }^{1}$, Supriyono ${ }^{2}$, Arif Sumardiono ${ }^{3}$ \\ Politeknik Negeri Cilacap, Kota Cilacap, Jawa Tengah, Indonesia ${ }^{1,2,3}$ \\ email: vcahyaguntara@gmail.com ${ }^{1}$
}

\begin{abstract}
This study aims to make a chili grinder and dryer with an automatic system using an Arduino Uno Atmega 328 microcontroller. This research is based on where Indonesia is an agricultural country that has abundant plant diversity, especially in agriculture. Chili plants are one of the agricultural commodities that are widely found in Indonesia and have been known for a long time by the public for various needs, one of which is food seasoning. According to the Central Statistics Agency (2017), in 2018, the production of large chilies including Indonesian red chilies reached 1.2 million tons. Commodities are produced in almost every province in Indonesia. The ten provinces that produce the largest chili peppers in Indonesia are West Java, Central Java, North Sumatra, West Sumatra, East Java, Aceh, Lampung, South Sumatra, Bengkulu, and Jambi. Chili plants experienced a very significant price decline at the beginning of the COVID-19 pandemic which hampered the distribution process and resulted in rotten chilies. To prevent spoilage, a simple drying process is needed by using a grinder and drying chilies with a size of $50 \mathrm{~cm} \times 12 \mathrm{~cm} \times 50 \mathrm{~cm}$. This machine is able to make chili weighing $200 \mathrm{~g}$ in 5 minutes at a temperature of $60^{\circ} \mathrm{C}$ and can remove $44 \%$ water content and lost water weight. weighing $88 \mathrm{~g}$ with temperature and time settings via a Microcontroller.
\end{abstract}

Keywords: Chili, Mikrokontroler, Moisture Content

Abstrak

Penelitian ini bertujuan merancang dan membuat alat penggiling dan pengering cabai dengan sistem otomatis menggunakan mikrokontroler arduino uno Atmega 328. Penelitian ini didasari dimana Indonesia merupakan negara agraris yang memiliki keanekaragaman tumbuhan yang melimpah, terutama pada bidang pertanian. Tanaman cabai merupakan salah satu komoditas pertanian yang banyak ditemukan di Indonesia dan telah dikenal lama oleh masyarakat untuk berbagai macam kebutuhan, salah satunya sebagai bumbu penyedap makanan. Menurut Badan Pusat Statistik (2017), Pada tahun 2018, produksi cabai besar termasuk cabai merah Indonesia mencapai 1,2 juta ton. Komoditas tersebut dihasilkan hampir di setiap provinsi di Indonesia. Sepuluh provinsi yang menghasilkan cabai besar terbes ar di Indonesia adalah Jawa Barat, Jawa Tengah, Sumatera Utara, Sumatera Barat, Jawa Timur, Aceh, Lampung, Sumatera Selatan, Bengkulu, dan Jambi. Tanaman cabai mengalami penurunan harga sangat signifikan pada saat awal pandemi covid 19 yang menghambat proses distribusi dan mengakibatkan cabai busuk. Untuk mencegah pembusukan diperlukan proses pengeringan yang simpel dengan menggunakan mesin penggiling dan pengering cabai dengan ukuran p x 1 x t yaitu $50 \mathrm{~cm}$ x $12 \mathrm{~cm}$ x $50 \mathrm{~cm}$. Mesin ini mampu mengeringkan cabai seberat 200 g dalam waktu 5 menit dengan suhu $60^{\circ} \mathrm{C}$ dapat menghilangkan kadar air seberat $44 \%$ dan berat air yang hilang seberat 88 g dengan pengaturan suhu dan waktu melalui piranti mikrokontroler.

Kata Kunci: Cabai, Mikrokontroler, Kadar Air

\section{PENDAhUluan}

Indonesia merupakan negara agraris yang memiliki keanekaragaman tumbuhan yang melimpah, terutama pada bidang pertanian. Tanaman cabai merupakan suatu komoditas pertanian yang sangat berpotensi di Indonesia dan telah dikenal lama oleh masyarakat untuk berbagai macam kebutuhan, salah satunya sebagai penyedap makanan. Indonesia sendiri memiliki iklim tropis yang sangat cocok untuk ditanami tanaman cabai dengan berbagai varietas. Daerah penanaman cabai sangat luas karena dapat ditanam di dataran rendah maupun dataran tinggi, sehingga banyak petani di Indonesia yang menanam cabai [1].

Menurut Badan Pusat Statistik (2017), Pada tahun 2018, produksi cabai besar (termasuk cabai merah) Indonesia mencapai 1,2 juta ton. Komoditas tersebut dihasilkan hampir di setiap provinsi di Indonesia. Sepuluh provinsi yang menghasilkan cabai besar terbesar di Indonesia adalah Jawa Barat, Jawa Tengah, Sumatera Utara, Sumatera Barat, Jawa Timur, Aceh, Lampung, Sumatera Selatan, Bengkulu, dan Jambi. Cabai merupakan komoditas hortikultura penting di Indonesia yang tidak dapat dipisahkan dari kebutuhan seharihari, terutama penggunaannya dalam skala rumah tangga. Jenis cabai yang umum ditemui pada pasar Indonesia antara lain adalah cabai besar (Capsicum annum) dan cabai rawit (Capsicum frutescens) [2].
Cabai selalu mengalami fluktuasi harga yang ditentukan oleh masa panen. Kekhawatiran lain yang sering terjadi pada cabai selain harganya yang tidak menentu adalah karakteristik cabai yang mudah rusak, sehingga tingkat kesegarannya sulit dipertahankan. Jenis kerusakan pada cabai umumnya adalah kerusakan biologis dan kerusakan patologis. Cabai mempunyai prospek cerah sebagai komoditas yang bernilai ekonomi tinggi karena salah satu pemanfaatannya sebagai bahan baku industri. Komoditas ini dari sisi lain juga mempunyai peluang sebagai komoditas ekspor dan dapat menaikkan ekonomi negara dan pendapatan petani itu sendiri. Penanganan pasca panen cabai masih sangat kurang diperhatikan, sehingga perlu adanya penanganan yang dapat mempertahankan nilai ekonomi dan komoditi tersebut, salah satunya melalui pengeringan. Pengeringan dimaksudkan untuk menghilangkan sejumlah air dari bahan yang dikeringkan dengan cara penguapan. Produksi yang melimpah pada saat panen raya dapat ditangani melalui pengeringan. Pengeringan secara garis besar dapat dilakukan dengan dua cara, yaitu pengeringan alami dan buatan.

Pengeringan juga diperlukan untuk mengurangi kerugian pasca panen pada situasi saat ini yang berdampak pada petani dengan adanya pandemi Covid 19. Pandemi covid 19 ini merugikan petani hingga cabai sulit untuk dipasarkan dan juga mengakibatkan cabai hasil panen dibuang. Untuk mengatasi permasalahan tersebut penulis membuat alat yang 
dapat menggiling sekaligus mengeringkan cabai dengan tujuan untuk menambah nilai jual cabai dan dapat menambah produk untuk UMKM baru.

Pada penelitian sebelumnya pengeringan cabai menggunakan cara putaran rak untuk menghasilkan cabai dengan kadar air berkurang sampai $11 \%$ dalam waktu 16 jam dengan suhu 60 ${ }^{\circ} \mathrm{C}$ hal tersebut memakan waktu yang cukup lama dan mengurangi efisiensi kerja, di penelitian yang baru penulis menggunakan sistem pengering cabai otomatis dengan mikrokontroler, heater 500 watt dan timer pengeringan untuk menghasilkan cabai kering dengan pengurangan kadar air yang mencapai $44 \%$ dalam waktu 5 menit pada suhu $60^{\circ} \mathrm{C}$.

\section{METODE PENELITIAN}

Metode yang digunakan dalam penelitian ini adalah merancang sebuah alat penggiling dan pengering cabai menggunakan sistem semi otomatis yang dikontrol dengan mikrokontroler arduino uno atmega 328.

\section{A. Diagram Blok Sistem}

Diagram blok sitem merupakan bagian dari skema perancangan penelitian alat penggiling dan pengering cabai ini. Karena diagram ini memaparkan prinsip kerja secara keseluruhan dari sitem yang digunakan, sehingga mempermudah proses perancangan alat sesuai diharapkan. Diagram blok dari sistem alat ini dapat dilihat pada Gbr .

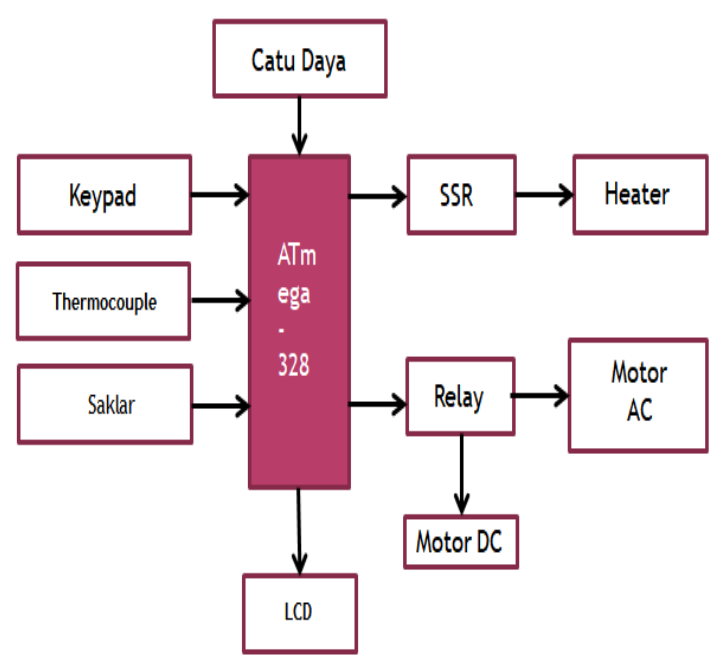

Gbr 1. Diagram Blok Sitem

Perancangan sistem ini bersifat semi-otomatis menggunakan atmega 328 sebagai komponen utama yang memproses perintah dan kemudian dieksekusi oleh output, Catu daya sebagai sumber untuk menyalakan atmega 328, Keypad untuk memasukan nilai suhu dan waktu yang dibutuhkan, Thermocouple sebagai sensor suhu untuk mengindera suhu pada proses pengeringan, Relay untuk mengaktifkan motor AC dan motor DC, SSR untuk mengaktifkan heater.

\section{B. Diagram Alir}

Flowchart atau diagram alir merupakan diagram yang berisi langkah - langkah kerja alat, setiap langkah dalam sebuah sistem digambarkan dengan sebuah simbol aliran langkahnya dinyatakan dengan garis yang dilengkapi dengan anak panah. Pada skema flowchart berisi tahap input dan output yang merupakan gambaran data yang sedang diproses dan informasi yang dihasilkan. Agar data yang dihasilkan sesuai dengan kebutuhan.

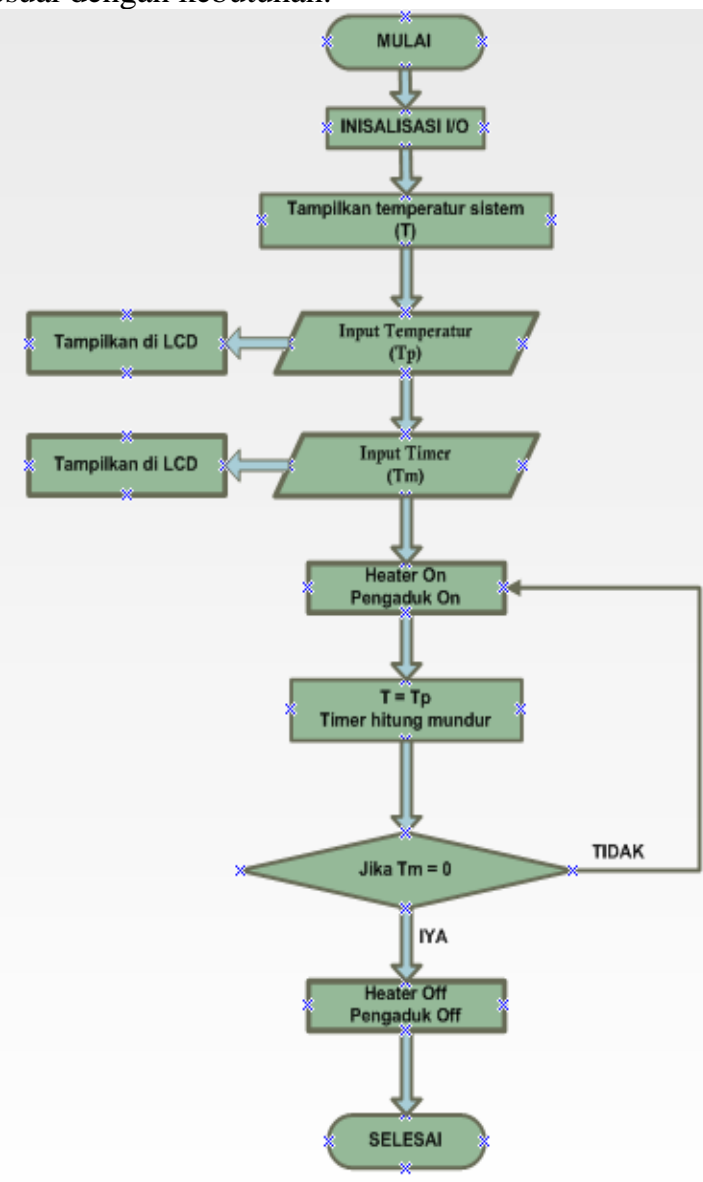

Gbr 2 Flowchart Pengeringan Cabai

Program dimulai dengan proses inisialisasi, lalu lcd menampilkan temperatur sistem, selanjutnya menginput suhu dan waktu. Setelah proses input suhu dan input waktu maka heater on, pengaduk on dan waktu menghitung mundur sampai $\mathrm{Tm}=0$. Jika waktu sudah 0 maka heater dan pengaduk off.

\section{Perancangan Sistem Mekanik}

Pada perancangan rangkaian elektronika, yang dimaksud disini yaitu proses pembuatan layout mulai dari schematic rangkaian hingga ke layout PCB menggunakan software Fritzing.

\section{Rangkaian LCD}

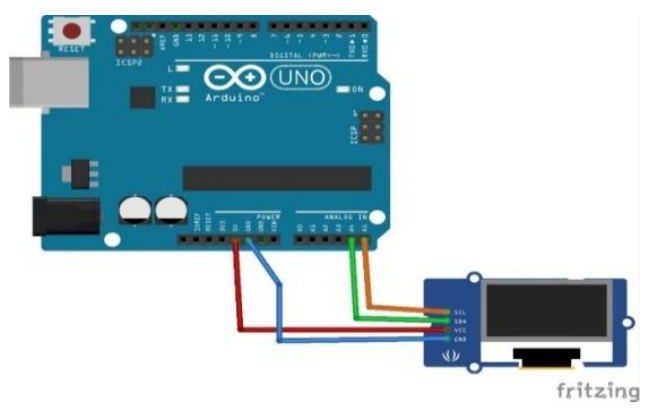

Gbr 3. Wiring Rangkaian LCD 
Tbl 1. Wiring LCD dengan Atmega 328

\begin{tabular}{cc}
\hline Arduino Atmega 328 & LCD \\
\hline 5V & VCC \\
\hline GND & GND \\
\hline A4 & SDA \\
\hline A5 & SCL \\
\hline
\end{tabular}

Display LCD 20x4 berfungsi sebagai penampil nilai kuat induksi medan elektromagnetik yang terukur oleh alat. LCD yang digunakan pada alat ini mempunyai lebar display 4 baris 20 kolom atau biasa sisebut sebagai LCD Character 20x4, dengan pin konektor [3].

LCD yang terhubung dengan arduino bertujuan untuk memonitoring suhu dan waktu pada proses pengeringan. Wiring untuk kabel merah $5 \mathrm{~V}$ yang terhubung dengan VCC LCD,kabel biru Ground terhubung dengan GND pada LCD,Untuk kabel Hijau dan Orange A4 dan A5 terhubung dengan SDA dan SCL pada LCD.

2. Rangkaian Thermokopel type- K
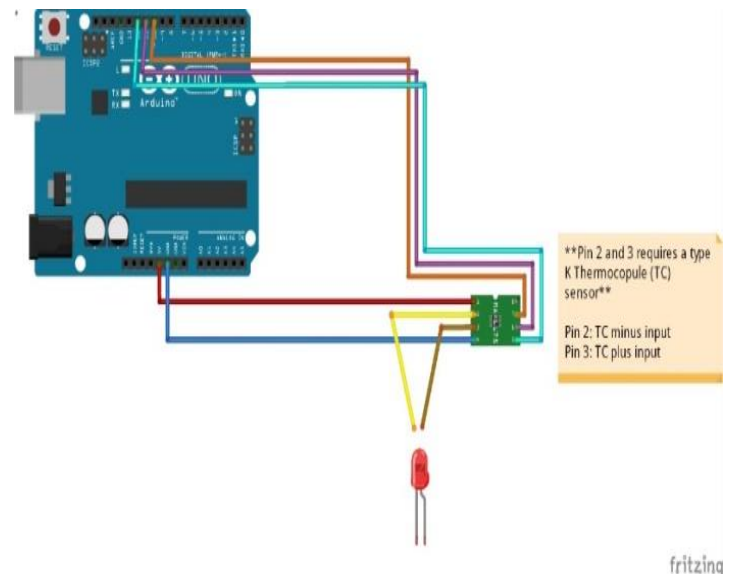

Gbr 4. Wiring Rangkaian Thermokopel type - K dengan Atmega 328

Tbl 2. Wiring Rangkaian Thermokopel type - K dengan ATmega 328

\begin{tabular}{cc}
\hline $\begin{array}{c}\text { Arduino Atmega } \\
328\end{array}$ & $\begin{array}{c}\text { Thermocople Type } \\
-\mathrm{K}\end{array}$ \\
\hline $5 \mathrm{~V}$ & VCC \\
\hline GND & GND \\
\hline Pin 10 & SO \\
\hline Pin 11 & CS \\
\hline Pin 12 & SCK \\
\hline
\end{tabular}

Termokopel tipe K terdiri dari nikel dan kromoium pada sisi positif (Thermocouple Grade) sedangkan sisi negatif negatif (Extension Grade) terdiri dari nikel dan alumunium. Thermocouple jenis ini sering dipakai pada tujuan umum dikarenakan cenderung lebih murah. Tersedia untuk rentang suhu $-200^{\circ} \mathrm{C}-1250^{\circ} \mathrm{C}[9]$.

Thermokopel sebagai sensor suhu dikoneksikan dengan arduino dengan wiring input digital. Pada arduino menggunakan pin 10,11, dan 12. Masing-masing terkoneksi dengan pin termokopel SO,CS, dan SCK. Output arduino diarahkan pada sumber panas untuk mendeteksi suhu yang ada.

\section{Rangkaian Keypad Matrix 4 x 4}

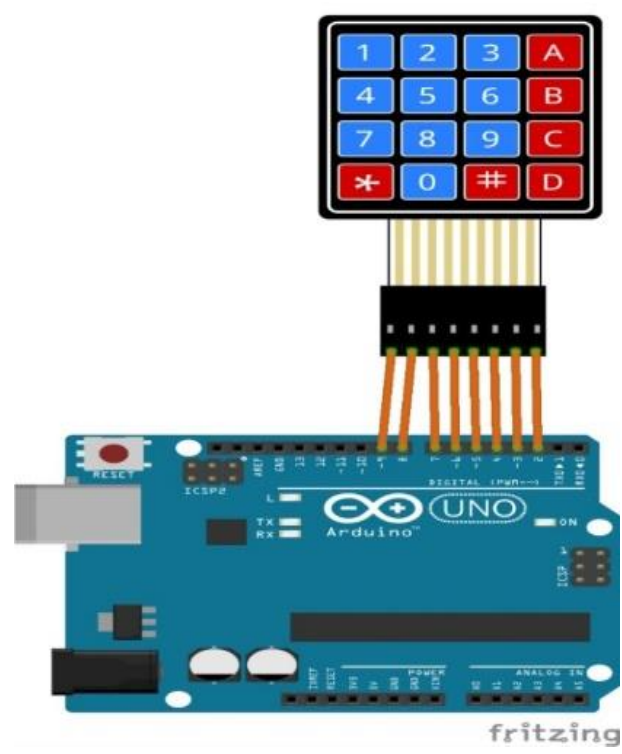

Gbr 5. Wiring Keypad

Tbl 3. Wiring Keypad dengan Atmega 328

\begin{tabular}{cc}
\hline Arduino Atmega 328 & Keypad \\
\hline Pin 2 & 8 \\
\hline Pin 3 & 7 \\
\hline Pin 4 & 6 \\
\hline Pin 5 & 5 \\
\hline Pin 6 & 4 \\
\hline Pin 7 & 3 \\
\hline Pin 8 & 2 \\
\hline Pin 9 & 1
\end{tabular}

Keypad adalah saklar-saklar push button yang disusun secara matriks yang berfungsi untuk menginput data seperti, input pintu otomatis, input absensi, input datalogger dan sebagainya. Saklar-saklar push button yang menyusun keypad yang digunakan umumnya mempunyai 3 kaki dan 2 kondisi. Kondisi pertama yaitu pada saat saklar tidak ditekan, maka antara kaki 1, 2, dan 3 tidak terhubung (berlogika 1). Sedangkan pada kondisi kedua adalah saat saklar ditekan, maka kaki 1, 2 dan 3 akan terhubung dan berlogika 0 [3].

Keypad yang terkoneksi dengan Arduino digunakan untuk memasukan nilai suhu dan waktu untuk prsoses pengeringan,membaca pin keypad dari kiri kekanan 18, sedangkan pin pada arduino dari kanan ke kiri $2-9$. 
4. Rangkaian Keseluruhan Sistem

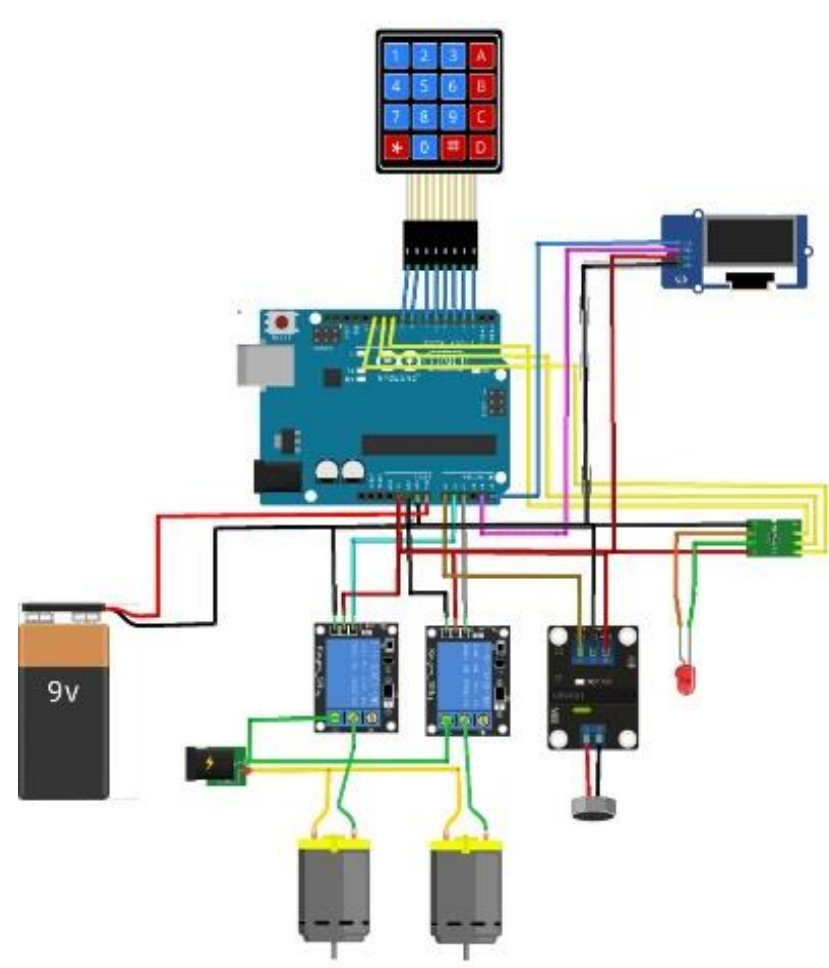

Gbr 6. Wiring Keseluruhan Sistem

Rangkaian ini menggambarkan rangkaian keseluruhan untuk alat pengering dan penggiling cabai yang membutuhkan keypad matrix $4 \times 4$, Atmega 328, dua relay untuk mengaktifkan motor ac dan motor dc secara otomatis, LCD sebagai monitor suhu dan timer, SSR untuk mengaktifkan heater. Heater sebagai sumber panas proses pengeringan cabai.

Dengan cara kerja Atmega 328 sebagai komponen inti sebagai memory program yang menerima perintah dari perangkat input dan dieksekusi perangkat output. Input suhu dan timer pada keypad, LCD menampilkan suhu dan timer, atmega mentramisikan perintah ke output relay mengaktifkan heater dan motor listrik. Timer count down $\mathrm{Tm}=0$ proses pengeringan otomatis berhenti.

\section{Perancangan Mekanik Alat}

Perancangan mesin pengering cabai yang menggunakan heater sebagai sumber panas diperlukan alat dan bahan serta komponen yang tepat. Alat dan bahan komponen harus dapat digunakan dan bekerja sesuai dengan fungsinya. Pemilihan komponen yang digunakan juga berpengaruh pada kualitas hasil mesin pengering cabai, Perancangan alat meliputi perancangan rangka dan perancangan pengaduk.

Kerangka terbuat dari besi siku berukuran $3 \mathrm{~cm} \times 3 \mathrm{~cm}$ dengan panjang $50 \mathrm{~cm}$, lebar $12 \mathrm{~cm}$, dan tinggi $50 \mathrm{~cm}$. Besi siku dipilih untuk bahan rangka karena kuat untuk pengaduk menggunakan bahan stainles steel karena bahan tersebut cocok untuk bahan yang bersentuhan dengan makanan dan lebih tahan terhadap karat.

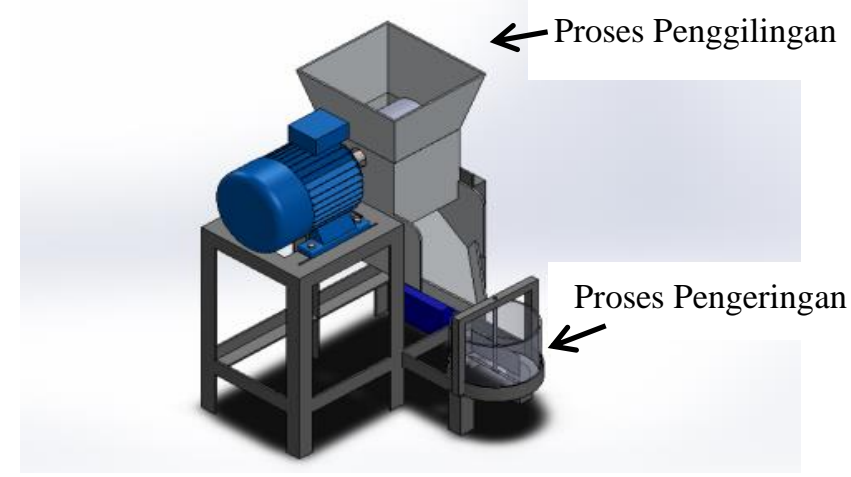

Gbr 7. Desain Alat

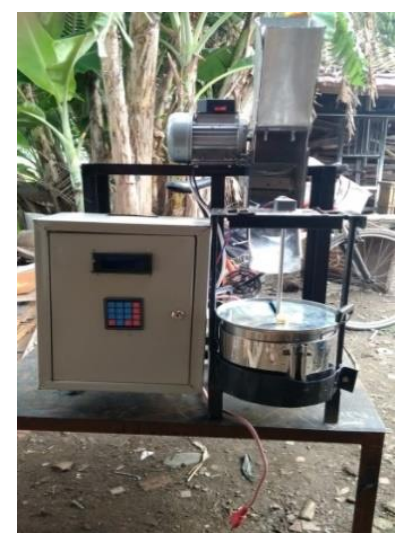

Gbr 8. Alat Penggiling dan Pengering Cabai dengan Mikrokontroler Atmega 328

\section{HASIL DAN PEMBAHASAN}

\section{A. Pengujian Kadar Air}

Proses pengeringan kadar air merupakan proses untuk menghilangkan kadar air dalam cabai. Hal ini dikarenakan, dalam proses pengeringan cabai terjadi pengurangan masa karena cabai yang baru digiling masih banyak mengandung air sehingga perlu dikeringkan agar tidak mengganggu besar nilai kalor dan laju pembakaran.

Pengujian ini dimaksudkan untuk mengetahui kadar air yang hilang dari cabai setelah melalui proses pengeringan dengan berat yang sama yaitu $200 \mathrm{~g}$ dan suhu yang sama yaitu $60^{\circ} \mathrm{C}$.

Tbl 4. Pengujian Kadar Air

\begin{tabular}{ccccc}
$\begin{array}{c}\text { Waktu } \\
\begin{array}{c}\text { Pengujian } \\
\text { (Menit) }\end{array}\end{array}$ & $\begin{array}{c}\text { Sebelum } \\
\text { (gram) }\end{array}$ & $\begin{array}{c}\text { Sesudah } \\
\text { (gram) }\end{array}$ & $\begin{array}{c}\text { Kadar air } \\
\text { menguap } \\
(\%)\end{array}$ & $\begin{array}{c}\text { Berat } \\
\text { air } \\
\text { yang } \\
\text { hilang } \\
\text { gram })\end{array}$ \\
\hline 1 & 200 & 148 & 26 & 52 \\
\hline 2 & 200 & 138 & 31 & 62 \\
\hline 3 & 200 & 130 & 35 & 70 \\
\hline 4 & 200 & 123 & 38,5 & 77 \\
\hline 5 & 200 & 112 & 44 & 88 \\
\hline
\end{tabular}




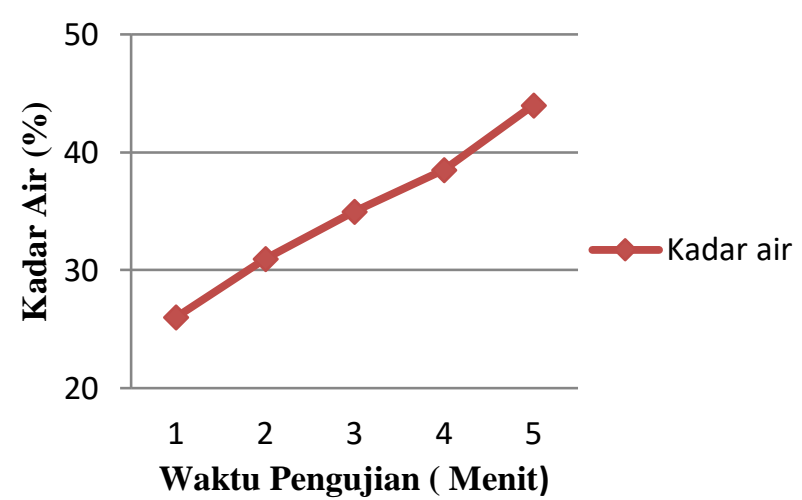

Gbr 9. Grafik Kadar Air

Berdasarkan Gbr 10. Jumlah kadar air yang menguap pada satu menit pertama mencapai $26 \%$, naik menjadi $31 \%$ di dua menit, naik menjadi $35 \%$ pada menit ke tiga pengujian, naik menjadi $38,5 \%$ saat menit ke empat,dan menit ke lima pengujian kadar air yang hilang mencapai $44 \%$.

Kadar air yang hilang mengakibatkan bau gosong jika proses pengeringan masih aktif, suhu pada luas penampang yang kecil mengakibatkan kenaikan suhu cukup signifikan dan mempercepat proses pengeringan.

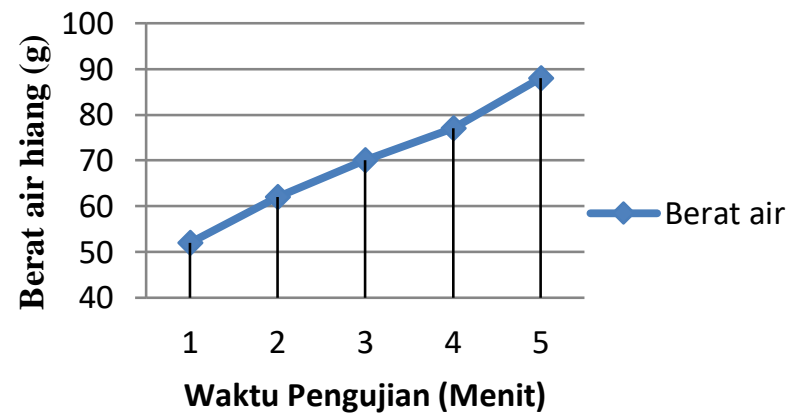

Gbr 10. Grafik Berat Air yang Hilang

Grafik diatas menjelaskan statistik berat air yang hilang pada cabai setelah proses pengeringan selama 5 kali percobaan per menit. Waktu pengujian selama satu menit berat air yang menghilang mencapai 52 gram. Proses pengeringan selama 5 menit menghilangkan air pada cabai mencapai 88 gram.

Dimana :

$$
\text { Pengeringan kadar air }=\frac{m 1-m 2}{m 1} \times 100 \%
$$

$\mathrm{M}_{1}=$ massa awal (gr)

$\mathrm{M}_{2}=$ massa setelah dikeringkan (gr)

Penjabaran perhitungan kadar air dengan berat awal $200 \mathrm{~g}$ :

Berat akhir dalam satu menit $\quad=148$ gram

$26 \%$

$$
=\frac{200-148}{200} \times 100 \%=
$$

Berat akhir dalam dua menit $\quad=138$ gram

$31 \%$
Berat akhir dalam tiga menit

$$
=130 \text { gram }
$$

$35 \%$

$$
=\frac{200-130}{200} X 100 \%=
$$

Berat akhir dalam empat menit $\quad=123$ gram

$38 \%$

$$
=\frac{200-123}{200} \times 100 \%=
$$

Berat akhir dalam lima menit $\quad=112$ gram

$44 \%$

$$
=\frac{200-112}{200} \times 100 \%=
$$

Pada hasil percobaan pengujian kadar air dapat diketahui hasil dari sempel pengujian yang terdapat pada tabel. Hasil pengujian yang baik pada saat pengeringan dalam waktu 5 menit menghasilkan kadar air yang menguap $44 \%$. Menguapnya kadar air dipengaruhi waktu dan suhu pada saat proses pengeringan yang ditentukan dengan mensetting mikrokontroler.

B. Pengujian Arus Listrik Keseluruhan

Pengujian ini dimaksudkan untuk megetahui arus yang mengalir ketika pengeringan berjalan. Dengan waktu yang berbeda menggunakan multimeter digital.

Tbl 5. Pengujian Arus Listrik Keseluruhan

\begin{tabular}{cc}
\hline Waktu (Menit) & Arus (Ampere) \\
\hline 1 & 5,25 \\
\hline 2 & 5,28 \\
\hline 3 & 5,29 \\
\hline 4 & 5,32 \\
\hline 5 & 5,40 \\
\hline Rata - rata & 5,30 \\
\hline
\end{tabular}

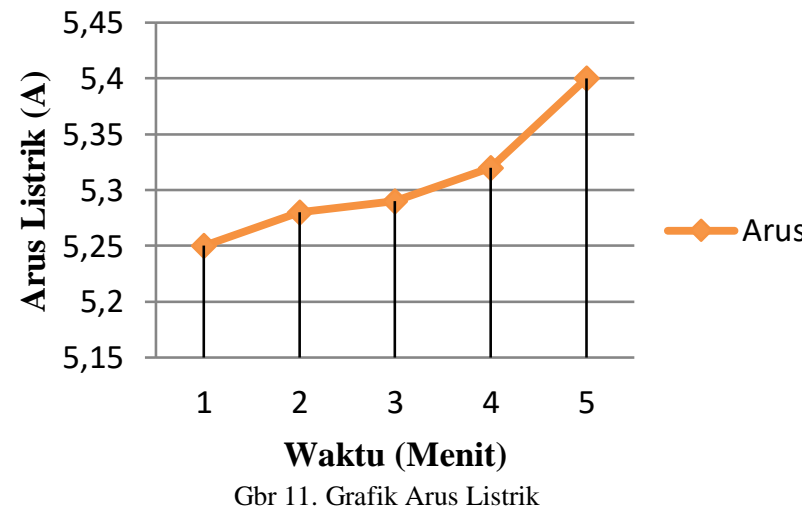

Berdasarkan grafik pengujian arus listrik pada saat mesin baru on selama satu menit memerlukan arus sebesar 5,25 A. Menit ke dua arus meningkat menjadi 5,28 A. Menit ke tiga arus sedikit naik menjadi 5,29 A. Pada menit ke empat arus naik cukup signifikan menjadi 5,32. Menit ke 5 arus naik menjadi 5,40. Naiknya arus dikarenakan heater yang semakin panas. 
Pada hasil pengujian arus yang mengalir pada saat mesin dihidupkan rata rata yang mengalir mencapai 5,30 A dengan pengukuran arus menggunakan multimeter secara paralel pada rangkaian sitem keseluruhan.

\section{Perhitungan Daya Keseluruhan}

Perhitungan daya yang digunakan pada alat pengering dan penggiling cabai untuk mengetahui daya yang digunakan pada saat proses pengeringan dan penggilingan cabai dalam waktu tertentu dan hasil rata rata arus yang digunakan.

Dengan diketahuinya rata-rata arus maka dapat menentukan daya yang digunakan dengan cara :

$$
\begin{aligned}
\mathrm{P} & =\mathrm{V} \times \mathrm{I} \times \operatorname{Cos} \mathrm{Q} \\
\text { Daya } & =190 \times 5,30 \times 0,86 \\
& =866 \mathrm{~W}
\end{aligned}
$$

Jadi,daya yang dipakai selama satu kali proses mencapai $866 \mathrm{~W}$. Dengan daya yang mencapai $866 \mathrm{~W}$ mesin dapat beroperasi dengan maksimal pada industri yang memilki daya 900 VA. Daya yang besar tersebut dipengaruhi oleh heater yang memiliki daya sebesar $500 \mathrm{~W}$. Penggunaan mesin pengering dan penggiling cabai selama proses ini memerlukan biaya tagihan listrik, untuk menentukan biaya tagihan listrik dapat menggunakan perhitungan sebagai berikut :

$$
\begin{aligned}
& 866 \times 1 \mathrm{Jam}=866 \text { watt } \\
& 866: 1000=0,866 \mathrm{kWh} \\
& 0,866 \times \operatorname{Rp} 1.325=\operatorname{Rp} 1.147 / \text { hari } \\
& \text { Rp } 1.147 \text { x } 30 \text { hari }=\operatorname{Rp~34.423/bulan~}
\end{aligned}
$$

Jadi, biaya listrik untuk penggunaan alat ini selama satu bulan yang harus di bayar mencapai Rp 34.423.

\section{Pengujian LCD}

Pengujian sistem penampil data menggunakan LCD karakter 20x4. LCD dihubungkan ke LCD backpack dimana dua buah kaki LCD backpack dihubungkan ke sumber tegangan lalu dua buah kaki yan lain dihubungkan Arduino. Program penampil data dibuat sesuai dengan kolom dan baris yang diinginkan. Pengaturan baris dan kolom pada penampil LCD dapat ditulis seperti $(0,2)$ dimana angka nol merupakan pengaturan letak baris dan angka dua merupakan pengaturan letak kolom. Hasil pengujian menunjukkan bahwa LCD dapat menampilkan data sesuai pengaturan program.

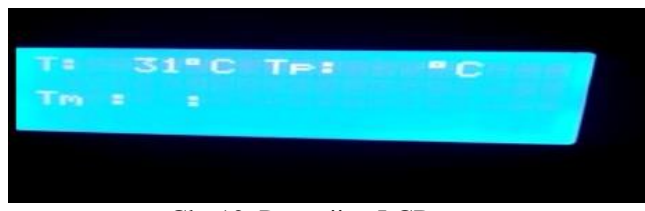

Gbr 12. Pengujian LCD

\section{KESIMPULAN}

Pengaruh suhu dalam proses pengeringan memberikan hasil kualitas tingkat kekeringan pada cabai yang telah digiling, standar kadar air pada cabai kering menurut dinas pertanian mencapai $40 \%$ - 50\% penyusutan kadar air pada suhu ruang $60^{\circ} \mathrm{C}$. Pada penelitian ini telah dilakukan uji kadar air jumlah kadar air yang menguap pada satu menit pertama mencapai $26 \%$, naik menjadi $31 \%$ di dua menit, naik menjadi $35 \%$ pada menit ke tiga pengujian, naik menjadi 38,5\% saat menit ke empat, menit ke lima pengujian kadar air yang hilang mencapai 44\%. Pengaruh laju kadar air menguap dikarenakan penggunaan heater yang memiliki daya yang besar mencapa $500 \mathrm{~W}$, sehingga mengakibatkan kenaikan suhu yang cukup signifikan. Proses pengeringan dan penggilingan dalam satu kali proses mengkonsumsi daya 866W dengan rata - rata arus listrik 5,30 A.

\section{REFERENSI}

[1] E. A. Parfiyanti, R. Budihastuti, and E. D. Hastuti, "Pengaruh Suhu Pengeringan yang Berbeda Terhadap Kualitas Cabai Rawit ( Capsicum frutescens L .) Indonesia merupakan negara agraris yang memiliki keanekaragaman tumbuhan yang pada bidang semua buah yang rasa pedas dari cabai . Capsaicinoid merupakan dan Pa," Biologi, vol. 5, no. 1, pp. 82-92, 2016.

[2] BPS Subdirektorat Statistik Perdagangan Dalam Negeri, Pola Distribusi Perdagangan Komoditas Cabai Merah Tahun 2019. 2019.

[3] F. B. Setiawan, M. Rizqiyanto, and J. U. M. Yiwa, "Oven Terprogram Berbasis Mikrokontroler," Widya Tek., vol. 21, no. 2, pp. 10-14, 2013.

[4] U. S. Utara, U. S. Utara, and U. S. Utara, "Penggunaan Thermocouple Type K pada Oven Pemanggang Kue Sebagai Sensor Temperatur Berbasis Mikrokontroler Atmega 328," 2019

[5] G. A. Putri, M. Sarosa, and L. D. Mustafa, "Implementasi Internet of Things Untuk Sistem Telecontrol Pada Oven Pengering Bahan Makanan Menggunakan Aplikasi Android," Jartel, vol. 9, no. 1, pp. 532-538, 2019, [Online].

[6] Syafriyudin and D. P. Purwanto, "Oven Pengering Berbasis Mikrokontroler Atmega 8535 Menggunakan Pemanas Pada Industri Rumah Tangga,” J. Teknol., vol. 2, no. 1, pp. 70-79, 2009.

[7] D. T. Papebatha, "Rancang Bangun Alat Pengering Singkong Berbasis Arduino," Semin. Has. Elektro S1 ITN Malang, 2019.

[8] T. I. Munandar and M. Kamal, "Temperatur Pada Proses Pemanggangan Ikan Tuna Secara Otomatis Menggunakan Arduino Uno Atmega328," vol. 3, no. 2, pp. 75-80, 2019.

[9] E. L. Zaky, R. Hakim, and H. Hasan, "Perancangan Mesin Pengering Hasil Pertanian Secara Konveksi Dengan Elemen Pemanas Infrared Berbasis Mikrokontroler Arduino Uno Dengan Sensor Ds18B20,” J. Karya Ilm. Tek. Elektro, vol. 2, no. 3, pp. 16-20, 2017.

[10] H. Priono et al., "Desain Pencacah serabut Kelapa dengan Penggerak Motor," 2019.

[11] A. R. Nugraha, A. Pengaduk, A. A. P. Adonan, and I. Pendahuluan, "Sistem Pengaturan Kecepatan Motor DC pada Alat Pengaduk Adonan Dodol Menggunakan Kontroler PID," no. Dc, pp. 1-6.

[12] Rusliansyah, "Analisa Mcb 2 Ampere pada Kwh Meter 30 Rumah di Desa Jambat Balo Kec. Pagaralam Selatan Kota Pagaralam," Foreign Aff., vol. 91, no. 5, pp. 1689-1699, 2016. 
[13] Eko Kustiawan, "Meningkatkan Efisiensi Peralatan dengan Menggunakan Solid State Relay (SSR) dalam Pengaturan Suhu Pack Pre-Heating Oven (PHO), " CIR J. STT YUPPENTEK, vol. 9, no. 1, pp. 1-6, 2018.

[14] A. S. I. Akbar, "Rancang Bangun Prototype Sistem Pemanggang Kue ( Oven ) Otomatis dengan Menggunakan Mikrokontroler Avr Atmega 8535," vol. 1, no. 2, pp. 69-81, 2014. 